\title{
Angiotensin-Converting Enzyme (ACE) Inhibitory Effects of Hazelnut Protein Hydrolysate Prepared Using Pepsin
}

\author{
Evren Caglar Eroglu ${ }^{1 *}$, Salih Aksay ${ }^{2}$ \\ ${ }^{1}$ Alata Horticultural Research Institute, Department of Postharvest Physiology, Mersin, TURKEY. \\ ${ }^{2}$ University of Mersin, Department of Food Engineering, Mersin, TURKEY.
}

\begin{abstract}
Objective / Purpose: The aim of this study is to find out the effect of protein isolate and pepsin hydrolysates of hazelnut protein on Angiotensin-Converting Enzyme (ACE) inhibition. Material and Methods: Unshelled hazelnuts (Corylus avellana L.) was firstly grinded and defatted by petroleum ether. Alkaline extraction and isoelectric precipitation method was used in order to obtain protein isolate. Neutralized protein suspension was freeze dried before analysis and stored at $-18^{\circ} \mathrm{C}$. Pepsin hydrolysis was conducted at $\mathrm{pH}$ 2 with $1: 20(\mathrm{w}: \mathrm{w})$ enzyme/substrate ratio at $37^{\circ} \mathrm{C}$ for $60 \mathrm{~min}$. Hydrolysis was stopped by heating samples to $85^{\circ} \mathrm{C}$ for enzyme inactivation and hydrolysates were analyzed for ACE inhibitory effect. $100 \mu \mathrm{L}$ of $2 \mathrm{mM} \mathrm{HHL}, 20 \mu \mathrm{L}$ of hydrolysate and $20 \mu \mathrm{L}$ of $2 \mathrm{mU}$ of ACE were incubated in $37^{\circ} \mathrm{C}$ for $60 \mathrm{~min}$. Reaction was terminated by adding $85 \mu \mathrm{l}$ of $1 \mathrm{M} \mathrm{HCl}$. Shimadzu HPLC system with C18 column and DAD was used for ACE inhibition analysis. Results and Discussion: Hazelnut protein isolate and peptides have over $95 \%$ ACE inhibition. On the other hand, IC50 values of samples taken at 0,30 and 60 minutes of pepsin hydrolysis were $1.29 \mathrm{mg}$ protein $/ \mathrm{ml}, 0.25 \mathrm{mg}$ protein $/ \mathrm{mL}$ and $0.22 \mathrm{mg}$ protein $/ \mathrm{mL}$, respectively. Conclusion: Results shows that hazelnut protein isolate and peptides have reasonable ACE inhibition properties. Pepsin hydrolysates of hazelnut isolates gives almost 6 times more anti-hypertensive activity than hazelnut protein isolate.
\end{abstract}

Key words: Hazelnut, Pepsin Hydrolysis, ACE Inhibition, Anti-Hypertensive.

\section{INTRODUCTION}

Hypertension is of primary important disease all over the world. ${ }^{1-5}$ Change of life style and pace of life trigger number of patients day by day. ${ }^{6}$ However, increasing of cost of illness as well as awakening divert people and governments to find alternative way. ${ }^{7}$ Functional foods have always been good alternative treatment. ${ }^{8-12}$ Although there are numerous studies on functional properties of animal and plant-derived bioactive proteins, plant-derived protein studies become prominent on the ground that they are cheap and readily available. ${ }^{13,14}$ In order to increase bioactive properties of proteins, they are usually digested to peptides. Peptides, by enzymatic hydrolysis or other digesting methods, can be obtained and purified for functional properties.

In this study, defatted and purified hazelnut isolates and pepsin hydrolyzed peptides were investigated for angiotensin converting enzyme inhibitory activity.

\section{MATERIAL AND METHODS}

Hazelnut (Corylus avellana L.) was purchased from local market (Turkey). Hippuric acid (HA), N-Hippuryl-His-Leu hydrate powder (HHL), pepsin from porcine gastric mucosa and Angiotensin Converting Enzyme (ACE) from rabbit lung (0.25 unit) were purchased from Sigma-Aldrich. The other chemicals were of analytical grade.
DOI: 10.5530/ijper.51.3s.59 Correspondence: Evren Caglar Eroglu, Alata Horticultural Research Institute, Department of Postharvest Physiology, Mersin, TURKEY. Phone no: 0090-5055482936 Email Id : evcager@gmail. com 


\section{Defatting of Hazelnut Flour}

$100 \mathrm{gr}$ of hazelnut fruits with shell were hydrated with twice as much as water for $24 \mathrm{~h}$. In order to separate shell, rehydrated fruits were dried in an oven at $40^{\circ} \mathrm{C}$ for a night and grinded using a grinder. In order to remove fat, ether was added to ground meal and mixed using magnetic stirrer under fume hood for $8 \mathrm{~h}$. Meal was filtered using coarse paper under vacuum. This procedure was repeated 2 times. Excess ether was removed by drying in oven at $40^{\circ} \mathrm{C}$.

\section{Preparation of Protein Isolate and Hydrolysis}

Protein isolate was prepared according to modified methods of Siddeeg et al. ${ }^{15}$ Method was based on isoelectric point precipitation. Defatted hazelnut meal was extracted in 1:8 (hazelnut meal/water) in $\mathrm{pH} 9$ (prepared by $1 \mathrm{~N} \mathrm{NaOH}$ ) for $1 \mathrm{~h}$. and centrifuged at $9,000 \mathrm{~g}$ for $15 \mathrm{~min}$. This procedure was repeated 2 times more to collect all protein. For isoelectric point precipitation, $\mathrm{pH}$ was adjusted to 4.5 with $1 \mathrm{~N} \mathrm{HCl}$ and entire protein was precipitated for $30 \mathrm{~min}$. Supernatant was extracted. And pellet was neutralized using $1 \mathrm{~N} \mathrm{NaOH}$. Hazelnut isolate was freeze dried for and stored $-20^{\circ} \mathrm{C}$. Protein content was determined by micro-Kjeldhal method, AACC. ${ }^{16}$

Pepsin hydrolysis of hazelnut isolate was carried at $\mathrm{pH}$ 2 at $37^{\circ} \mathrm{C}$ for $60 \mathrm{~min}$. Enzyme/substrate ratio was 1:20. Samples were taken at 0 min (hazelnut protein isolate), $30 \mathrm{~min}$ (P30) and $60 \mathrm{~min}$ (P60) of hydrolysis. All samples were aliquoted and stored at $-20^{\circ} \mathrm{C}$ until analyzed.

\section{ACE Inhibitory Activity}

ACE Inhibitory activity was determined by some modifications of method described by Wu and Ding. ${ }^{17}$ ACE catalyzes normally whole HHL to form hippuric acid (HA) in case of being non-inhibitor (called as control sample). ACE inhibitory activity of hazelnut protein was determined after adding protein isolate or peptides (called as inhibitor sample) and monitored for differences between inhibitor samples and control samples using HPLC.

$20 \mu \mathrm{L}$ of $2.0 \mathrm{mU}$ ACE, $20 \mu \mathrm{L}$ hazelnut protein hydrolysate and $100 \mu \mathrm{L}$ of a $2.0 \mathrm{mM}$ HHL were mixed and incubated for $1 \mathrm{~h}$. Enzymatic activity was stopped by adding $85 \mu \mathrm{L}$ of $1 \mathrm{M} \mathrm{HCl}$. It is assumed that control samples produce $100 \%$ of HA. Percent of inhibitory activity of protein $(\% \mathrm{INH})$ was calculated as follows:

$\% \mathrm{INH}=1$ - (HA of inhibitor sample / HA of control sample) $\times 100$

HA analysis was carried out by Shimadzu HPLC with PDA detector. Mobile phase were $0.05 \%$ acetonitrile (A) and water (B). First 10 min solvent A was increased
Table 1: Percent of ACE Inhibitory Activity (\%INH) of Hazelnut Protein Isolate and Peptides

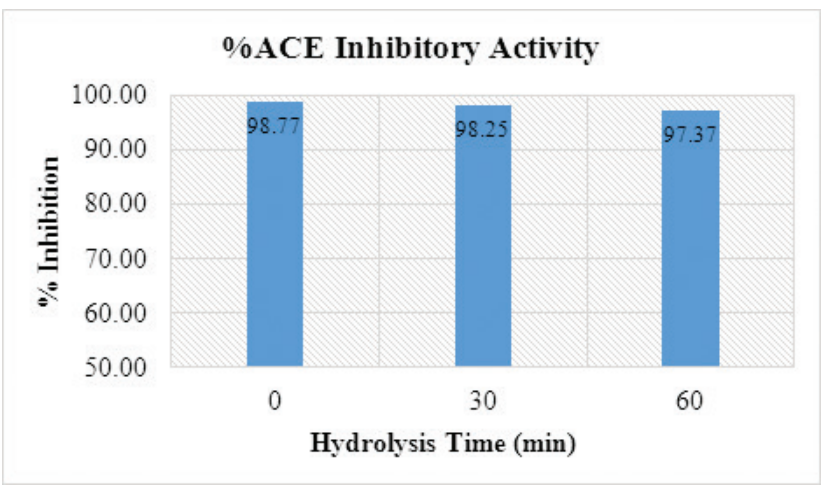

Table 2: IC50 values of Hazelnut Protein Isolate and Peptides

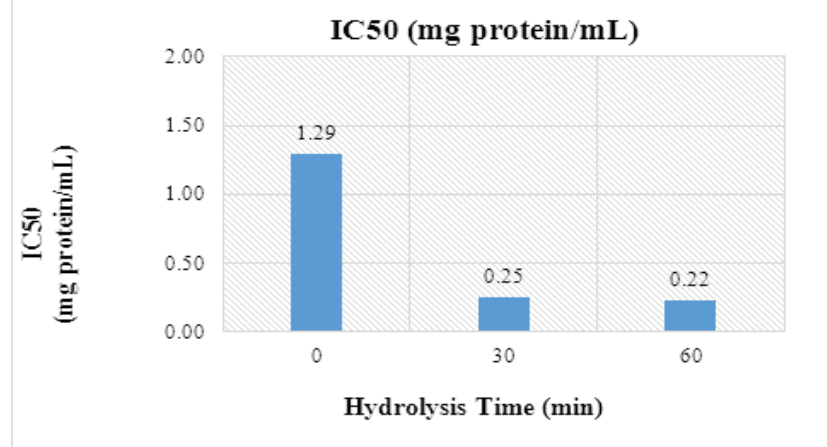

linearly from 5 to $60 \%$. After 2 min isocratic elution, it was decreased to $5 \%$ acetonitrile. Elution was finished after $4 \mathrm{~min}$ at this level. Flow rate was $1 \mathrm{ml} / \mathrm{min}$.

$\mathrm{IC}_{50}$ value, concentration of protein isolate to inhibit $50 \%$ of ACE, was calculated by diluting samples with 5-100X dilution factor.

\section{Statistical analysis}

All results were analyzed by one-way analysis of variance (ANOVA) using SPSS. Mean values were analyzed Tukey's test $(\mathrm{p}<0.05)$.

\section{RESULTS \& DISCUSSION}

In this study, antihypertensive activity (ACE inhibition activity) of hazelnut isolate and hazelnut peptides were determined. Table 1 shows ACE inhibitory activity of hazelnut protein isolate sample (taken at the beginning of hydrolysates) and 2 different hazelnut peptides samples (P30 and P60).

According to results, it was realized that samples inhibited more than $95 \%$ of ACE. There were a slight decreasing of \% INH throughout hydrolysis. Although \%INH 
values of protein isolate and P30 samples were not statistically different $(p=0.25)$, that of protein isolate sample and P60 were significantly different $(p=0.02) . \%$ INH of hazelnut protein isolate was comparable with previous studies. According to Siddeeg et al. ${ }^{18}$ hazelnut protein had 94.2\% ACE inhibitory activity. Moreover, $\%$ INH of whey protein concentrate was defined as $88.6 \%{ }^{19}$ According to Quist et al. ${ }^{20} \mathrm{ACE}$ inhibitory activity of peanut protein increased from $66 \%$ to $97 \%$ after alcalase hydrolysis.

In order to compare the results with literature, it was necessary to calculate the amount of protein that inhibits $50 \%$ of ACE. This amount of protein is called as $\mathrm{IC}_{50}$. $\mathrm{IC}_{50}$ values of isolate and peptides were given Table 2. Although all samples resulted in more than $95 \%$ of ACE inhibition, their protein contents were averagely $28.12 \mathrm{~g}$ protein $/ \mathrm{mL}$. In order to define $\mathrm{IC}_{50}$, samples were diluted with 2-100 X diluting factor. $\mathrm{IC}_{50}$ values of control sample was determined as $1.29 \mathrm{~g}$ protein $/ \mathrm{mL}$. P30 and P60 samples had almost one sixth of control sample's $\mathrm{IC}_{50}$ value, which were 0.25 and $0.22 \mathrm{~g}$ protein $/ \mathrm{mL}$, respectively. Decreasing of $\mathrm{IC}_{50}$ means more antihypertensive activity. P30 and P60 samples had 5.16 and 5.86 times more $\mathrm{IC}_{50}$ activity than protein isolate sample, respectively. $\mathrm{IC}_{50}$ of P30 and P60 were not significantly different $(p=0.72)$. According to Aydemir et al., ${ }^{18} \mathrm{IC}_{50}$ of hazelnut protein isolate was found $1.0 \mathrm{mg}$ protein $/ \mathrm{mL}$. This value was comparable with present study. Despite limited studies of hazelnut protein, there were lots of studies on $\mathrm{IC}_{50}$ of some nuts and cereals. $\mathrm{IC}_{50}$ of alcalase hydrolyzed peanut protein was determined as $0.548 \mathrm{mg} / \mathrm{mL} .^{21} \beta$-conglycinin and glycinin hydrolysates of soy protein gave an $\mathrm{IC}_{50}$ values ranging between from 0.126 to $0.340 \mathrm{mg} / \mathrm{mL}^{22}$ Moreover, $\mathrm{IC}_{50}$ of dried and wet corn germ was found between 3.26 to $7.77 \mathrm{mg} /$ $\mathrm{mL} .{ }^{23}$ and $\mathrm{IC}_{50}$ of whey protein concentrate without hydrolysis was clarified as $0.20 \mathrm{mg} / \mathrm{mL}^{19}$

\section{CONCLUSION}

ACE inhibition capacity of defatted and purified hazelnut protein isolate can be good alternative to synthetic and some natural ACE inhibitors. Although $\mathrm{IC}_{50}$ of hazelnut isolate has a remarkable $\mathrm{IC}_{50}$ value, peptides of hydrolyzed hazelnut protein can result by far the best $\mathrm{IC}_{50}$.

\section{ACKNOWLEDGMENT}

This study was supported by the Research Fund of Mersin University in Turkey with Project Number: 2015-TP2-1246.

\section{CONFLICT OF INTEREST}

None

\section{ABBREVIATION USED}

HA: Hippuric acid; HHL: N-Hippuryl-His-Leu hydrate powder; ACE: Angiotensin Converting Enzyme; P0: Sample taken at the beginning of hydrolysis (Hazelnut isolate); P30: Samples taken at $30 \mathrm{~min}$ of hydrolysis; P60: Samples taken at $60 \mathrm{~min}$ of hydrolysis; \%INH: Percent of protein inhibitory activity; $\mathrm{IC}_{50}$ : Concentration of protein isolate to inhibit $50 \%$ of ACE.

\section{REFERENCES}

1. Yang HY, Yang SC, Chen RR, Tzeng YH, Han BC. Soyabean protein hydrolysate prevents the development of hypertension in spontaneously hypertensive rats. Brit J Nutr. 2004;92(3):507-12.

2. Shuangquan, Tsuda $\mathrm{H}$, Miyamoto T. Angiotensin I-converting enzyme inhibitory peptides in skim milk fermented with Lactobacillus helveticus 130B4 from camel milk in Inner Mongolia, China. J Sci Food Agr. 2008;88(15):2688-92.

3. Amalia CY, Rissyelly, Katrin. ACE inhibitory activity, total phenolic and flavonoid content of watercress (Nasturtium officinale $\mathrm{R}$. Br.) extract. Pharmacognosy Journal. 2017;9(2).

4. Xing Y, Liao J, Tang Y, Zhang P, Tan C, Ni H, et al. ACE and platelet aggregation inhibitors from Tamarix hohenackeri Bunge (host plant of Herba Cistanches) growing in Xinjiang. Pharmacognosy Magazine. 2014;10(38):111-7.

5. Vijayakumar B, Parasuraman S, Raveendran R, Velmurugan D. Identification of natural inhibitors against angiotensin I converting enzyme for cardiac safety using induced fit docking and MM-GBSA studies. Pharmacognosy Magazine. 2014;10(39):639-44.

6. Yang HY, Yang SC, Chen ST, Chen JR. Soy protein hydrolysate ameliorates cardiovascular remodeling in rats with L-NAME-induced hypertension. J Nutr Biochem. 2008;19(12):833-9.

7. Correa APF, Daroit DJ, Coelho J, Meira SMM, Lopes FC, Segalin J, et al. Antioxidant, antihypertensive and antimicrobial properties of ovine milk caseinate hydrolyzed with a microbial protease. J Sci Food Agr. 2011;91(12):2247-54.

8. Alfaro MD, Alvarez I, El Khor S, de Padilla FC. Functional properties of a protein product from Caryodendron orinocense (Barinas nut). Arch Latinoam Nutr. 2004;54(2):223-8.

9. Fagbemi TN. Effect of Processing on the Functional Properties of Full-Fat and Defatted Cashew nut (Anacardium occidentale) seed flours. J Food Sci Tech Mys. 2008;45(1):28-35.

10. Padilla FC, Alvarez MT, Alfaro MJ. Functional Properties of Barinas Nut Flour (Caryodendron orinocense Karst, Euphorbiaceae) compared to those of soybean. Food Chem. 1996;57(2):191-6.

11. Ahmad I, Yanuar A, Mulia K, Munim A. Review of angiotensin-converting enzyme inhibitory assay: Rapid method in drug discovery of herbal plants. Pharmacognosy Reviews. 2017;11(21):1-7.

12. Lobo V, Patil A, Phatak A, Chandra N. Free radicals, antioxidants and functional foods: Impact on human health. Pharmacognosy Reviews. 2010;4(8):118-26.

13. Adiamo OQ, Gbadamosi OS, Abiose $\mathrm{SH}$. Antioxidative and functional properties of kariya (Hildergadia barteri) protein hydrolysates obtained with two different proteolytic enzymes. J Food Process Pres. 2016;40(2):202-11.

14. Mahajan A, Rawat AS, Bhatt N, Chauhan MK. Structural modification of proteins and peptides. Indian J Pharm Educ Res. 2014;48(3):34-47.

15. Siddeeg A, Xu YS, Jiang QX, Xia WS. Physicochemical and functional properties of flour and protein isolates extracted from seinat (Cucumis melo var. tibish) seeds. Food Sci Biotechnol. 2014;23(2):345-53.

16. AACC. Crude Protein-Micro Kjeldhal method. In approved methods of the AACC. 2000;2(10):46-13. St. Paul, Minnesota, USA. 
17. Wu JP, Ding XL. Characterization of inhibition and stability of soy-proteinderived angiotensin I-converting enzyme inhibitory peptides. Food Res Int. 2002;35(4):367-75.

18. Aydemir LY, Gökbulut AA, Baran Y, Yemenicioğlu A. Bioactive, functional and edible film-forming properties of isolated hazelnut (Corylus avellana L.) meal proteins. Food Hydrocolloid. 2014;36:130-42.

19. Mullally MM, Meisel H, FitzGerald RJ. Angiotensin-l-converting enzyme inhibitory activities of gastric and pancreatic proteinase digests of whey proteins. Int Dairy J. 1997;7(5):299-303.

20. Quist EE, Phillips RD, Saalia FK. Angiotensin converting enzyme inhibitory activity of proteolytic digests of peanut (Arachis hypogaea L.) flour. Lwt-Food Sci Technol. 2009;42(3):694-9.
21. Zhang $\mathrm{YH}, \mathrm{Ma} \mathrm{L}$, Wang $\mathrm{Q}$. Bioactive peptides from low denatured peanut dregs: production and antihypertensive activity. In: Wang D, editor. Materials for Environmental Protection and Energy Application, Pts 1 and 2. Advanced Materials Research. Durnten-Zurich: Trans Tech Publications Ltd. 2012:343-

22. Kuba M, Tana C, Tawata S, Yasuda M. Production of angiotensin I-converting enzyme inhibitory peptides from soybean protein with Monascus purpureus acid proteinase. Process Biochem. 2005;40(6):2191-6.

23. Parris N, Moreau RA, Johnston DB, Dickey LC, Aluko RE. Angiotensin I converting enzyme-inhibitory peptides from commercial wet- and dry-milled corn germ. J Agr Food Chem. 2008;56(8):2620-3.

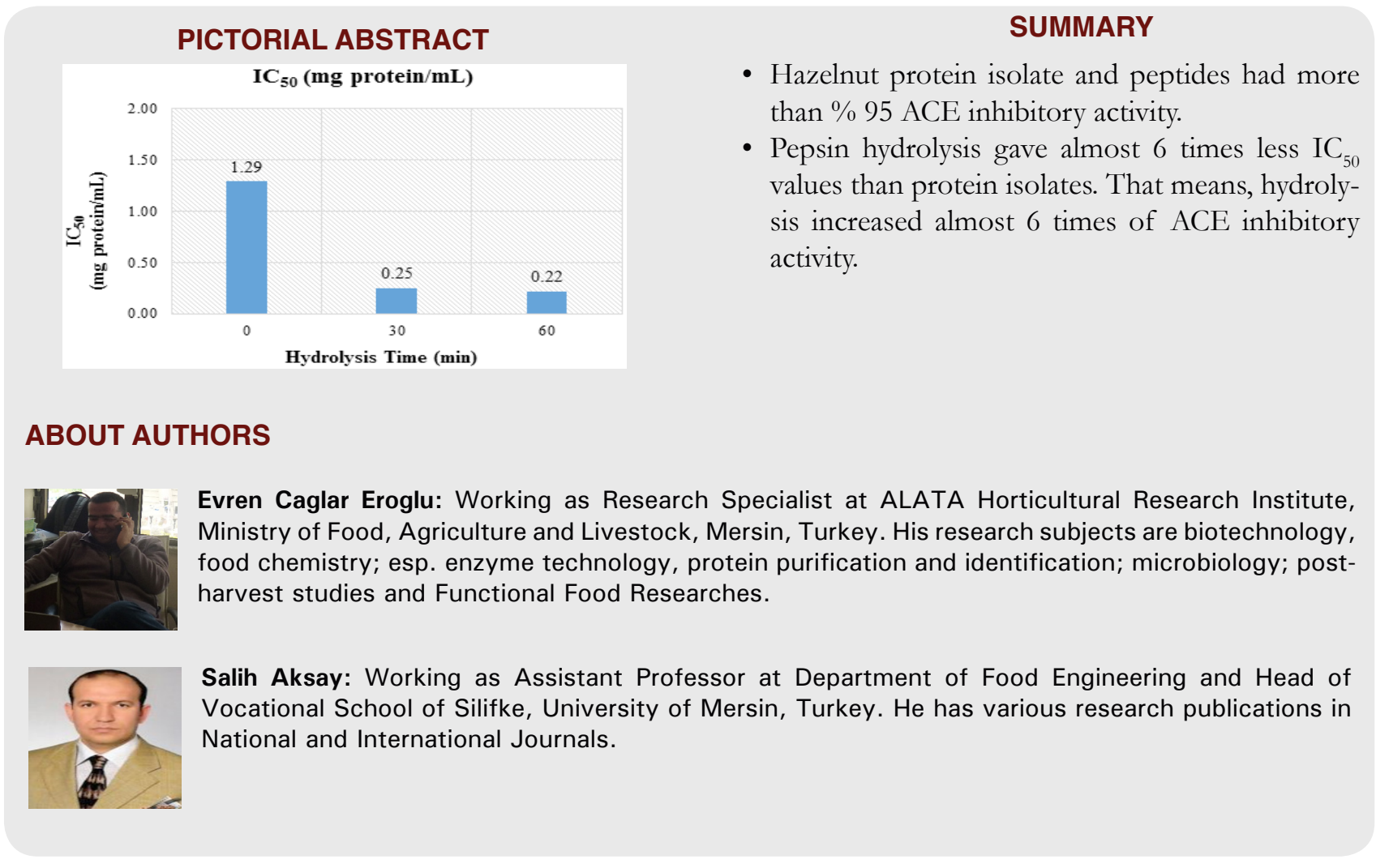

Cite this article: Eroglu EC, Aksay S. Angiotensin-Converting Enzyme (ACE) Inhibitory Effects of Hazelnut Protein Hydrolysate Prepared Using Pepsin. Indian J of Pharmaceutical Education and Research. 2017;51(3)Suppl:S417-20. 